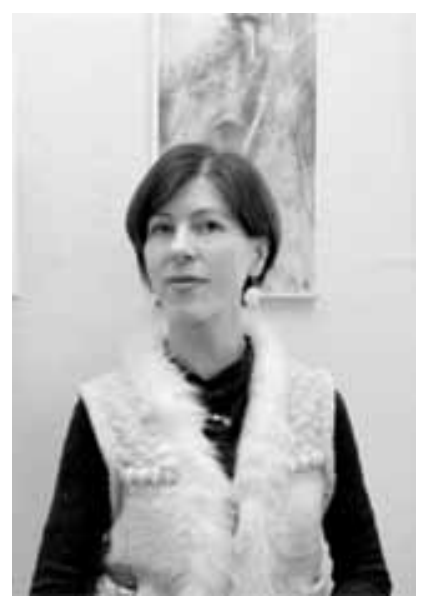

Jūratè Derukaitè - Klaipėdos universiteto Socialinių ir humanitarinių mokslų fakulteto Lituanistikos ir užsienio kalbų centro vadovè

Moksliniai interesai: taikomoji kalbotyra, vertimas, svetimujuc kalbų mokymo didaktika

El.paštas: lukc.shmf@ku.lt,polyglosia@gmail.com

Jūratè Derukaitè - philologist, Head of Centre for Lithuanian Studies and Foreign Languages, lecturer in the Department of Philology, Faculty of Social Sciences and Humanities, Klaipeda University (Lithuania)

Research interests: applied linguistics, teaching Lithuanian as a foreign language, teaching foreign languages, translation E-mail: polyglosia@gmail.com

\title{
Jūratè Derukaitè
}

Klaipedos universitetas

\section{LIETUVIŲ KALBOS \\ (KAIP NEGIMTOSIOS) MOKYMAS - KLAIPEDOS UNIVERSITETO TAPATYBES DALIS}

\section{Anotacija}

Straipsnyje įvairiais aspektais apžvelgiama Klaipėdos universiteto lietuvių kalbos kaip negimtosios mokymo veikla, apibendrintai vadinama lietuvių kalbos kursais. Apžvelgiamas laikotarpis apima du dešimtmečius iki 2020-ųjų metų.

PAGRINDINIAI ŽODŽIAI: lietuvių kaip negimtoji kalba, lietuvių kalbos kursai, Lietuvių kalbos ir kultūros vasaros / žiemos akademija, komunikacinis metodas, tarpkultūrinis bendravimas.

\section{Abstract}

The aim of the article is to describe various aspects of the study of Lithuanian as a foreign language at Klaipeda University during the last two decades. The survey deals with activities that come under Lithuanian language courses.

KEY WORDS: Lithuanian as a foreign language, Lithuanian-language courses, Lithuanian Language and Culture Summer/Winter Academy, communication method, intercultural communication.

DOI: http://dx.doi.org/10.15181/rh.v27i0.2164 


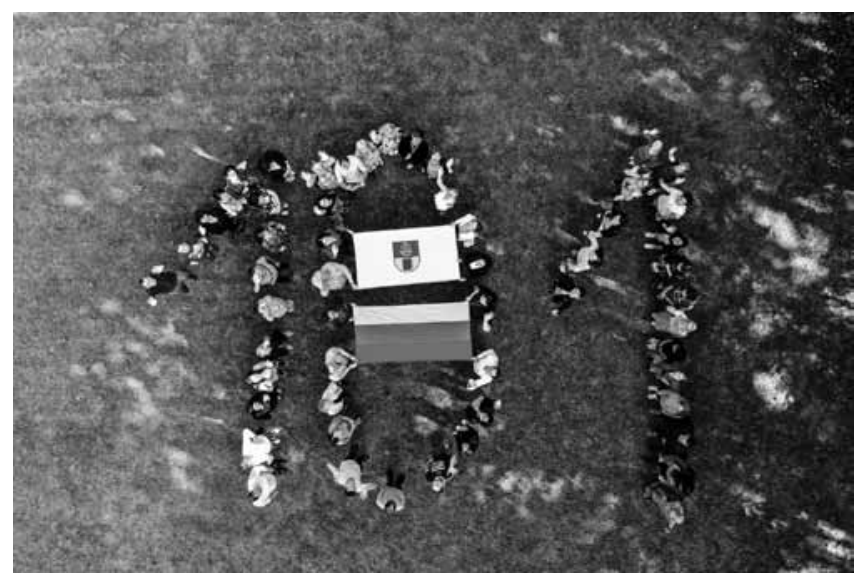

Per Lietuviu kalbos ir kultūros akademija

„, ¿i Klaipedą ateina pasaulis ir Lietuva išeina ị pasaulį“ (Darren van Rawensvaay, kanadietis, Klaipedos universiteto lietuvių kalbos kursų dalyvis)

I v a d a s

Šiame straipsnyje apžvelgiami Klaipėdos universiteto (toliau - KU) vykdomi lietuvių kalbos (kaip negimtosios ${ }^{1}$ ) mokymai, jų struktūra, specifika. Tai kompleksinis reiškinys, turintis gana daug sudedamųių dalių: KU lietuvių kalbos kaip negimtosios (toliau - L22 ${ }^{2}$ mokymų sistemos ištakos, kūrimas, struktūra, rinkodara; tikslinès grupès - besimokančių lietuvių kalbos asmenų - sudèties analizè; mokytojų darbo specifika (kalbos mokymo lygiai, metodika, mokomoji medžiaga ir kt.); sociokultūrinis aspektas ir dar daugiau dalykų. Kiekviena iš šių sudedamųjų dalių galètų būti atskiras išsamus tyrimas. Todèl čia stengtasi išanalizuoti ir aprašyti ši reiškinį kaip vienovę, augančią bei evoliucionuojančią sistemą, išryškinti spręstinus uždavinius, numatyti perspektyvas.

Klaipėdos universitete dabartinè lietuvių kalbos kaip L2 mokymo struktūra apima dvi sritis. Pirmoji - akademinè. Jai priskirtini laipsnio ir dalinèse studijose besimokantys užsieniečiai, studijuojantys lietuvių kalbą kaip privalomąji ar pasirenkamąij dalyką. Šias studijas administruoja Studijų tarnyba. Antroji sritis - tai neformalieji lietuvių kalbos mokymai, įvairios trukmès ir intensyvumo lietuvių kalbos kursai; jie yra arba mokami, arba vykdomi Švietimo mainu paramos fondo administruojamų programų lèšomis. Straipsnyje apžvelgiami būtent šie neformalieji mokymai, - nors, tiesa, abi apibrèžtosios sritys yra susijusios.

Apžvelgiamasis laikotarpis apima beveik du dešimtmečius iki 2020-ųių.

1 Literatūroje taip pat vartojami terminai lietuvių kalba kaip užsienio / svetimoji, tačiau čia pasirinkta vadinti lietuviu kalba kaip negimtoji.

2 Kalbotyroje vartojamas terminas L2 reiškia ,antroji kalba“; tačiau žmonijai vis labiau tampant daugiakalbe, L2 reiškia „antroji, trečioji etc. kalba“. 
Trumpa lietuvių kalbos kaip negimtosios mokymo Lietuvoje 1990-2020 m. apžvalga

Lietuvių kalbos kaip L2 mokymo(si) poreikis po Lietuvos nepriklausomybès atkūrimo i̇gavo naują kryptị. Iki tol mokymo metodika ir mokomoji medžiaga buvo orientuota daugiausia į tam tikras tikslines grupes (pavyzdžiui, skirta nelietuvių mokykloms arba tam tikrų tautybių užsieniečiams / kitakalbiams). Paminètina populiari 1989 m. išleista J. Aleksandravičiaus lietuvių kalbos mokymo(si) priemonė rusakalbiams asmenims. Tačiau ir tų mokymo priemonių tebuvo nedaug ir jos nebeatitiko poreikių, - reikejo universalesnès mokomosios medžiagos, naujos lietuviu kalbos kaip L2 mokymo koncepcijos.

1994 m. išleista E. Jakaitienès knyga „Lietuviškai apie Lietuvą“ buvo skirta pažengusiųiu lygiui ir parengta tekstų ịvairiomis kultūros temomis pagrindu. 1997 m. išleistas pirmasis detalus lietuviu kalbos kaip svetimosios mokymo(si) turinio aprašas - penkių autorių knyga „Slenkstis“. 1998 m. pasirodė M. Ramonienès ir L. Vilkienès lietuvių kalbos vadovèlis pradedantiesiems „Po truputic“; 2000 m. - V. Žulienès „Lietuvių kalbos pratybos kitakalbiams: mokomoji knyga“; 2001 m. - V. Stumbrienès ir V. Kaškelevičienès „Nè dienos be lietuvių kalbos: 12 pamokuc pradedantiesiems".

Lietuvių kalbos kaip L2 mokymo praktinès ir teorinès literatūros poreikis èmė ypač sparčiai augti Lietuvai ịstojus į Europos Sąjungą. „Lietuvių kalba kaip svetimoji - naujas lietuviu kalbos mokymo(si) patirties terminas, pradètas vartoti pastaraisiais metais, kai Lietuvai tapus visateise Europos Sąjungos (ES) nare atsirado sąlygos bendradarbiauti su įvairių sričių užsienio partneriais“ (Buivydienė, Žukienė 2006). Atliepiant sparčiai augančius poreikius, imta gausiau kurti metodinę ir mokomąją medžiagą: išleista J. Džežulskienės, R. Žukienės ir kitų autorių vadovèlių, gramatikų anglų kalba, mokomųju žodynų ir kitokio pobūdžio priemonių. Daugejo lituanistų, ịgyjančių lietuvių kalbos kaip L2 mokymo kvalifikaciją, kaupiama ir skleidžiama dèstymo patirtis.

İdomu tai, jog šio laikotarpio pradžioje mokomąsias priemones rengè ne tik lituanistai, bet ir anglistai, pavyzdžiui, D. Tekorienė, J. Janavičienė. Pastaroji autorė buvo lietuvių kalbos kaip L2 mokymo pradininkė Klaipèdos universitete, jos vadovèliai, skirti vokiečių, anglų ir rusų tautybès asmenims, pasirodė iškart po 2000-ųjų.

Kalbant apie lietuvių kalbos kaip L2 mokymo srities mokslinę literatūrą, pabrěžtina atliktų ir publikuotų darbų gausa; tuose tyrimuose nagrinejjami ịvairūs aspektai. Aptariamojo laikotarpio pradžioje aktualiausia buvo sukurti naują lietuvių kalbos kaip L2 mokymo koncepciją. Daug šioje srityje nuveikẻ Vilniaus universiteto (toliau - VU) Filologijos fakulteto Lituanistinių studijų katedros 
darbuotojai (žr. publikacijų sąrašą http://www.lsk.flf.vu.lt/lt/darbuotojai). Pažymètina, jog 2006 m. M. Ramonienei, L. Vilkienei, J. Pribušauskaitei, V. Stumbrienei už darbų ciklą „Lietuvių kalbos kaip svetimosios mokymas: situacijos tyrimas, metodika ir jos taikymas (1995-2005 m.)“ skirta Lietuvos mokslo premija.

Vèliau pagausėjo tyrimų konkrečiais metodikos, teorijų, technologijų taikymo ir kitais aspektais (V. Buivydienè, J. Džežulskienė, N. Mačianskienè, R. Žukienė), atskirais kalbos mokymo(si) klausimais, t. y. lietuvių tarpukalbès ${ }^{3}$ požiūriu. Šios srities tyrimų yra paskelbusi I. Savickienè (Dabašinskienė), J. T. Ramonaite ir kt.

Šiuo metu lietuvių kalbos kaip L2 mokoma daugybėje įvairių institucijų bei centrų Lietuvoje ir užsienyje. Informacija apie jų siūlomas programas viešinama šių mokymo centrų internetinèse svetainèse bei socialiniuose tinkluose, skirtuose ỉ Lietuvą atvykstantiems ar grịžtantiems asmenims (https://lietuva.lt/, https://www.renkuosilietuva.lt/, https://www.facebook.com/GlobaliLietuva/, www.lrt.lt/lituanica ir kt.). Be to, žiniasklaidoje pasirodo nemažai publicistinio pobūdžio straipsnių, nes tai ne tik aktuali visuomenei tema, bet kartu ir mokymo centrų reklama. Ypač daug rašyta apie dabartinès Vytauto Didžiojo universiteto (toliau - VDU) Švietimo akademijos (buvusio Lietuvos edukologijos universiteto) Lituanistinių studiju centro veiklą, kuriai daugeli metų vadovauja VDU Tarptautinių ryšių departamento Švietimo akademijos Tarptautinių ryšiu grupès vadovè Vilma Leonavičienè. Iš užsienyje veikiančių centrų būtina paminèti Sakartvelo technikos universiteto Tbilisyje Lietuvių kalbos ir kultūros centrą, kuriam vadovauja prof. Vidas Kavaliauskas. Be ilgametės ir intensyvios lietuviu kalbos mokymo veiklos, lietuvių ir kartvelų kultūros sklaidos, prof. V. Kavaliauskas inicijuoja ir vykdo kalbinių bei kultūrinių mainų projektus ir pelnytai vadintinas Lietuvos kultūros ambasadoriumi Sakartvele.

Klaipedos universiteto lietuvių kalbos neformaliųiu mokymų struktūra

Kaip minèta, Klaipėdos universitete lietuvių kalbos kaip L2 mokymas apima akademinę sritị (lietuvių kalbos dalykai laipsnio ir dalinių studijų studentams) ir neformaliuosius lietuvių kalbos mokymus, universitete apibendrintai vadinamus lietuviu kalbos kursais. Abi šios sritys turi sąlyti: moko tie patys dẻstytojai, gali būti naudojama tokia pati mokomoji medžiaga, laipsnio studijų studentai užsieniečiai gali mokytis bendrose grupèse su neformaliųų lietuvių kalbos kur-

3 Tarpukalbe (angl. interlanguage) kalbotyroje vadinama tam tikra kalbinė sistema, igytų kalbinių kompetencijų etapas mokantis svetimųų (negimtųjų) kalbų, evoliucionuojantis nuo pradinio iki aukščiausiojo lygio. 
sų dalyviais, dalyvauti bendruose kultūriniuose renginiuose. Toks organizacinis lankstumas suteikia įvairiapusę naudą.

Neformaliuosius lietuvių kalbos mokymus / kursus organizuoja KU Socialinių ir humanitarinių mokslų fakulteto Lituanistikos ir užsienio kalbų centras kartu su Filologijos katedra ${ }^{4}$. Šių lituanistinių studijų ciklas nenutrūksta visus kalendorinius metus:

- Metų ciklas pradedamas sausio mèn. intensyviais vieno ménesio trukmès kursais - Lietuvių kalbos ir kultūros žiemos akademija (toliau - Žiemos akademija). Pamokos vyksta nuo pirmadienio iki penktadienio (kasdien po 4 akademines kontaktinio darbo valandas). Kursų apimtis: 80 akademinių valandų (toliau - ak. val.) pamokų ${ }^{5}$, dar maždaug 40 papildomų (bet neprivalomų laisviesiems klausytojams) ak. val. skiriama kalbos praktikai ir kultūrinei-pažintinei programai: tai renginiai, išvykos, ekskursijos. Taip pat skiriamos savarankiško darbo valandos kasdienėms namų užduotims atlikti. Atkreiptinas dèmesys $\mathfrak{i}$ tai, kad Žiemos akademijoje (taip pat ir analogiškoje Vasaros akademijoje) sudaromos sąlygos dalyvauti ne tik visoje, bet ir dalyje šios mokomosios veiklos.

- Pavasario ir rudens semestru lietuvių kalbos kursai; pamokos vyksta kelis kartus per savaitę (priklausomai nuo kursų apimties - nuo 30 iki 50 ak. val.). Šiuc kursų dalyviams taip pat organizuojama kultūrinių renginių (pavyzdžiui, Kalèdų ar Velykų vakaronès).

- Lietuvių kalbos ir kultūros vasaros akademija (toliau - Vasaros akademija) yra Žiemos akademijos analogas. Šie intensyvūs kursai vyksta nuo liepos mènesio vidurio iki rugpjūčio vidurio. Tai didžiausias ir žinomiausias KU lituanistinių studijų kitakalbiams ciklo renginys.

- Individualios / specializuotos lietuvių kalbos mokymo programos vykdomos norinčiųju pageidavimu pagal suderintas sąlygas.

KU lietuvių kalbos kaip L2 mokymo sistema pasižymi tęstinumu ir lankstumu. Besimokantieji gali mokytis visą ciklą nenutrūkstamai arba praleisti kurị nors vieną etapą ir prisijungti vèlesniame ciklo renginyje - visada stengiamasi surinkti įvairių kalbos mokejjimo lygių grupes. Mokoma pagal „Bendrųų Europos kalbų metmenų“ nustatytą šešių kalbos mokejjimo lygių sistemą nuo A1 iki C2, kuri savo ruožtu atitinka trijų lietuvių kalbos kaip valstybinės mokejjimo kategorijų skalę, taigi KU kursų absolventai sėkmingai išlaiko valstybinės kalbos egzaminus.

Anksčiau visų trijų minètųjų padalinių pavadinimai buvo kitokie.

5 Kai kurios pamokos gali būti ir išvykstamoji praktinė veikla. 


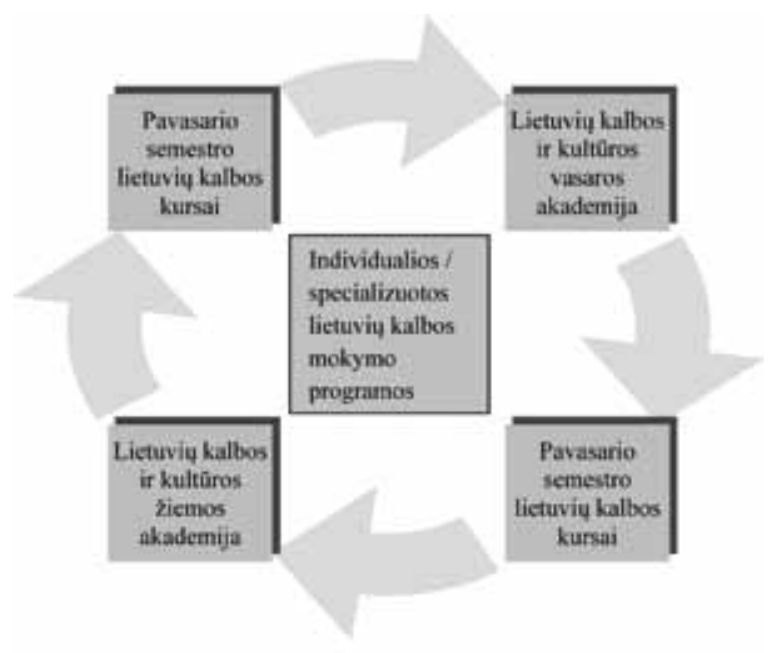

1 pav. KU neformaliųių lietuvių kalbos mokymų struktūra

Lietuviško žodžio sklaida: nuo Klaipedos iki tolimiausiuc pasaulio kampelių

Klaipėdos universiteto bendruomenė gerai žino: vasara kai kam yra intensyviausio darbo metas: Lituanistikos ir užsienio kalbų centras kartu su grupe lituanistų ruošiasi ir dirba didžiausiame KU lietuvių kalbos kaip L2 mokymo projekte - Vasaros akademijoje. Joje susiburia ir atvykstantys užsieniečiai, ir vietiniai gyventojai - Klaipėdoje ar Vakarų Lietuvos regione apsigyvenę kitataučiai. Natūralu, kad Vasaros akademija, lyginant su kitais per metus vykstančiais lietuvių kalbos kursais, pasižymi gausiausiu dalyvių skaičiumi, nes vasarą noriai naudojamasi proga turiningai ir ịdomiai praleisti atostogas. Tada sulaukiama daugiausia specialiai į šiuos kursus atvykstančių žmonių iš įvairiausių pasaulio vietų. Padaugèja ir vietinių užsieniečių, mokosi ir vienas kitas nelietuvių tautybės Lietuvos pilietis, panoręs tobulinti lietuvių kalbos žinias.

Vasaros akademija gerai žinoma ir miesto visuomenei. Nemažas lietuvių kalbos besimokančiųju būrys aktyviai dalyvauja miesto renginiuose, o tai patraukia žiniasklaidos dèmesį. Lietuviškai prabylantys užsieniečiai - įvairaus amžiaus, profesijų, skirtingų rasių ir religijų, kai kurie dėvintys neịprastus apdarus - kelia vietinių gyventojų susidomėjimą ir simpatiją. Visada klausiama šių dalykų: koks yra dalyvių skaičius ir iš kokių šalių atvykę, kokie yra besimokančiųjų motyvai, ar lietuvių kalba jiems sudetinga ir ką jie išmoksta.

Kalbant apie KU lietuvių kalbos kaip L2 mokymų žinomumą, galima drąsiai teigti, jog žinios bei atsiliepimai apie Vasaros / Žiemos akademiją (angl. 
Lithuanian Language and Culture Summer / Winter Academy) per beveik du dešimtmečius pasklido po visą pasaulį. Šalių, iš kurių atvykstama, sąrašas ilgas. Daugiausia (apie 2/3) kursantu būna iš Europos šalių; tolimiausios pasaulio vietos, iš kurių buvo atvykę KU kursų dalyviai, - Argentina, Australija, Filipinai, Indija, Indonezija, Japonija, JAV, Kanada, Kinija, Meksika, Naujoji Zelandija. Parvykę ị savo šalis, kursų dalyviai parveža ten savo patirtị bei įspūdžius ir dalijasi jais. Parašoma išsamių reportažų - ne tik apie lietuvių kalbos mokymą, dẻstytojus, Klaipedą, bet ir apskritai apie Lietuvą - jos kultūrą, istoriją ir t. t. Tai KU indẻlis į informacijos apie Lietuvą, jos kalbos ir kultūros sklaidą pasaulyje, todèl lietuvių kalbos kursų rengèjams ir dèstytojams natūraliai tenka ir patriotinè atsakomybė už tai, kad tie įspūdžiai būtų kuo geresni.

Kai kuriuos KU lietuvių kalbos kursų alumnus galima vadinti tikrais lietuvių kalbos ir kultūros, lietuvybès ambasadoriais: jie dalyvauja užsienio lietuvių bendrijų, lietuvių kalbos ir kultūros centrų veikloje (paminètina Kijevo Maironio lietuvių kultūros draugija, Lietuvių kalbos draugijos atstovybė Maskvoje, Sakartvelo technikos universiteto Lietuvių kalbos ir kultūros centras). Reikia paminèti ir KU lietuvių kalbos kursų alumnų dalyvavimą LR atstovybių užsienio valstybèse kultūrinèje veikloje.

Kai kurie lietuvių kalbos mokytis jau ne kartą atvykstantys užsieniečiai dalyvauja ne vieno Lietuvos universiteto kursuose. Pasimokius vienoje aukštojoje mokykloje, vèliau kalbos mokomasi kitoje, o po metų ar kelerių vèl grịžtama i tą pačią švietimo instituciją. Visur yra mokoma lietuvių kalbos, tačiau yra ir nemažai savitumų: kursų data, geografinė padètis, kultūrinė programa, mokymo metodika. Viena iš tokių kursančių, dalyvavusių ịvairiuose lietuvių kalbos kursuose skirtingose aukštosiose mokyklose, yra japonė Aya Kimura. KU Vasaros akademijoje ji dalyvavo du kartus. Ji inicijavo lietuvių kalbos ir kultūros centro įsteigimą Očanomizu (Ochanomizu) universitete Tokijuje. Aya Kimura ne tik dèsto lietuvių kalbą, bet ir verčia grožinę literatūrą: jau išleista keletas jos išverstų ¿̇ japonų kalbą knygu vaikams ir S. Nėries poezijos rinktinė.

Dar keli lietuvių kalbos kursų alumnai, mokęsi ir KU, ir kitų universitetų kursuose, jau įdiegė lietuvių kalbos dėstymą savo šalių aukštosiose mokyklose. Štai Kijevo nacionaliniame Taraso Ševčenkos universitete vyr. mokslinio bendradarbio doc. dr. Igorio Korolyovo iniciatyva lietuvių kalba įtraukta į filologijos bakalauro studiju programą Lenku kalba ir literatūra, anglu ir lietuvių kalbos; jis tapo ir pirmuoju lietuvių kalbos dėstytoju šioje programoje. O štai 2020 m. gegužès mènesi gauta žinia, jog lietuvių kalba, kaip pasirenkamoji, bus pradèta dèstyti Filipinų Dilimano universitete. Šiuo metu jau yra 10 ją pasirinkusių studentų, o desstytojas - dr. Ricky Giganto, dirbantis šio universiteto Europos kalbų katedroje. Abu šie filologai lietuvių kalbos pradèjo mokytis KU Vasaros akademijoje. 
Lietuvių kalbos dėstymas Filipinuose daug kam gali kelti nuostabą: kokie motyvai, tikslai, perspektyvos? Dr. R. Giganto'as Dilimano universitete dèsto kelias kalbas. Panoręs išmokti dar vieną Europos kalbą, rado galimybę atvykti pagal Švietimo mainu paramos fondo programą mokytis lietuvių kalbos; pasidomėjęs ir sužinojęs, jog tai seniausia indoeuropiečių kalba, jis pasvarsté, jog ateityje báltuc kalbų studijos galètu atsirasti ir Filipinuose. KU dėstytojams jis dèkingas už suteiktus tvirtus lietuvių kalbos tarties ir gramatikos pagrindus: „I owe to these effective teachers the solid foundation in pronunciation \& grammar of Lithuanian“, - rašo jis savo socialinio tinklo Facebook paskyroje.

Yra ir daugiau KU lietuvių kalbos kursų alumnų, dabar lietuvių kalbos mokančių savo tautiečius.

\section{Augimas ir kūrimasis}

Nuo KU įsteigimo $1991 \mathrm{~m}$. sausio 1 d. (jo pagrindas buvo trys stiprūs iki tol Klaipėdoje veikę kitu aukštųju mokyklų fakultetai) Vakarų Lietuvoje gausejjant atvykstančiu užsieniečių, formavosi atitinkamų lietuvių kalbos mokymų poreikis. KU pirmieji norintys mokytis lietuvių kalbos buvo pavieniai užsieniečiai. 1999 / 2000 studijų metais atvyko pirmieji studentai iš užsienio universitetuc pagal ES Socrates mainų programą. Brendo būtinybe universitete steigti lietuvių kalbos kaip L2 mokymo sistemą. Tos iniciatyvos ėmėsi tuometis Tarptautiniu ryšių skyrius.

2002 m. gavus kelias užklausas, surengti pirmieji KU Lietuvių kalbos vasaros kursai. Juose mokèsi 7 įvairių tautybių užsieniečiai. Tai buvo bandomasis renginys tiek organizaciniu, tiek ir kalbos dėstymo aspektu. Jau kitais metais, $2003 \mathrm{~m}$. vasarą, mokytis lietuvių kalbos atvyko gausus būrys dalyvių pagal Socrates paprogramę Erasmus (Erasmus intensyvūs kalbos kursai, angl. EILC). İ KU pradèjo vykti ir pirmieji užsienio universitetų studentai / dėstytojai / tyrèjai ir lietuvių kilmès užsieniečiai, atradę galimybę pasinaudoti Lietuvos Valstybiniu stipendiju lietuvių kalbos ir kultūros vasaros / žiemos kursams užsieniečiams programa (dabar ją administruoja Švietimo mainų paramos fondas, toliau vadinamas ŠMPF). Po kelerių metu santykis tarp minètų pirmosios ir antrosios kategorijos kursantų Klaipèdos universitete pakito - EILC kursantų mažejo ${ }^{6}$, o valstybès stipendininku - didejjo; pagal pastarąii skaičių KU ėmė pirmauti tarp kitu Lietuvos universitetų.

Nuo pačių pirmųju vasaros kursų svarbi jų dalis buvo kultūrinè-pažintinė programa: renginiai, išvykos, ekskursijos; ju metu daug dèmesio skirta ir kalbos

62012 m. Tarptautiniame seminare EILC organizatoriams ir dèstytojams svarstyta dèl tos paprogramės uždarymo ir kalbos mokymo perkèlimo į nuotolinę erdvę. 2020-ieji m., kaip numatyta, yra paskutiniai. 
praktikai. Taigi vasaros kursai buvo pavadinti Lietuvių kalbos ir kultūros vasaros mokykla. Lietuvai įstojus ị Europos Sąjungą 2004 m. ir lietuvių kalbai tapus viena iš oficialių ES kalbų, jos ėmè mokytis ir įvairūs ES institucijose dirbantys pareigūnai. Užsimezgus ryšiams, kelerius metus tokių pareigūnų (daugiausia vertėjų) atvykdavo ir į KU vasaros kursus, kur būdavo formuojama atskira ju grupè - kalbos buvo mokoma pagal specialią jiems parengtą programą.

Gausejjant Lietuvoje apsigyvenančių (laikinai ar ilgesniam laikui) užsieniečių, daugejjo ir norinčiųju mokytis lietuvių kalbos ne vasaros metu. Universitete sparčiai plečiantis lietuvių kalbos kaip L2 mokymo veiklai, jai koordinuoti įsteigtas specialus etatas tuomečiame Humanitarinių mokslų fakultete, o 2006 m. - Kalbų centras, šiuo metu vadinamas Lituanistikos ir užsienio kalbų centru (LUKC).

Norinčiųjų mokytis lietuvių kalbos skaičiaus augimas paskatino rengti ir intensyvius Lietuvių kalbos ir kultūros žiemos kursus, analogiškus vasaros kursams. Pirmieji įvyko 2015 m. sausio mėnesį - taip lituanistinių studijų kitakalbiams mokymai tapo nuosekliu ciklu, trunkančiu visus metus.

2016 m. vidiniu kursų rengejuu ir dèstytojų nutarimu - dèl pasiekto ir pripažinto aukšto akademinio lygio - nuspręsta intensyvius vasaros ir žiemos kursus pavadinti Lietuvių kalbos ir kultūros vasaros / žiemos akademija.

Būtina paminèti ir semestrų metu vykstančius lietuvių kalbos kursus, kuriems taip pat skiriamas didelis dėmesys. Juose mokosi Klaipėdoje ar Klaipėdos apskrityje gyvenantys kitataučiai, KU studentai, norintys išmokti kalbẻti lietuviškai. Dalis kursantų dalyvauja ir semestro kursuose, ir Vasaros / Žiemos akademijose.

Šiek tiek statistikos: kas ir kodèl mokosi lietuvių kalbos (kaip negimtosios)?

Neįmanoma nurodyti tikslaus skaičiaus, kiek žmonių, kokių tautybių, kokiu kalbos mokejiimo / mokymo lygiu mokèsi KU lietuvių kalbos kursuose per daugiau kaip 20 metų. Apytiksliai tokių dalyvių galètų būti arti 3000 .

Nuo 2002 m. surengta 19 intensyvių vasaros ir 6 žiemos kursai (nuo 2015 m.). Šiuo laikotarpiu taip pat nuolat vyko kursai semestro metu, kaip ir individualūs mokymai. Pastarųjų trejų metų duomenimis, vidutinė besimokančiųjų statistika yra tokia:

- Žiemos akademijoje sulaukiama apie 40-ies dalyvių;

- semestro kursuose vienu metu mokosi apie 10-15 laisvųjų klausytojų;

- Vasaros akademija pritraukia apie 60-70 norinčiųju mokytis lietuviu kalbos arba tobulinti jau turimas žinias;

- kursuose pagal individualias / specializuotas programas būna iki 10-ies dalyviu per metus. 


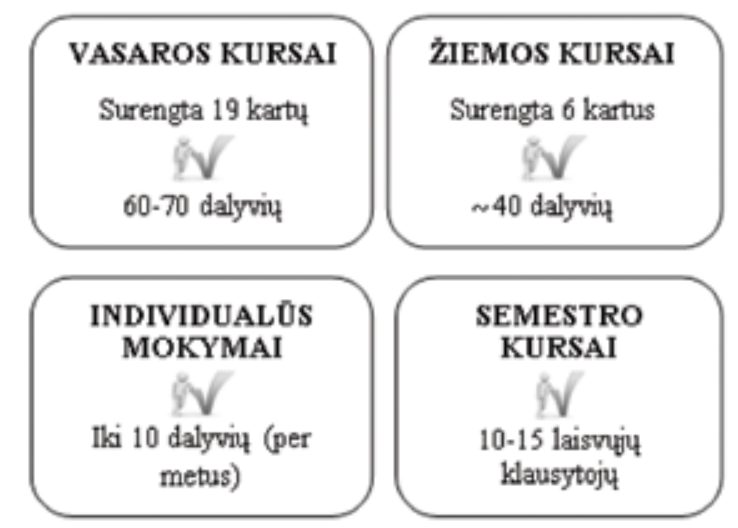

2 pav. KU neformaliųu lietuvių kalbos mokymų statistika

Šalių, iš kurių per du dešimtmečius turèta atvykusių arba Lietuvoje jau apsigyvenusių kursų dalyvių, užfiksuotas skaičius yra tikslus - 44. Jau minèta, jog norinčiųjų mokytis sulaukiama iš viso pasaulio, tačiau didesnè dalis būna iš Europos. Pažymètina, jog šalių sąraše - ir Lietuva; KU lietuvių kalbos kursuose yra mokęsi keli rusakalbiai moksleiviai, kuriems nepakako mokyklose vedamų pamokų, ir keli jauno amžiaus LR piliečiai, sugrịžę iš emigracijos (suprantama, sąvoka lietuvių kalba kaip negimtoji čia netinka).

KU lietuvių kalbos kursų dalyviai - tai moksleiviai, studentai, įvairiausių profesijų atstovai: verslininkai, žurnalistai, inžinieriai, švietimo ir mokslo srities specialistai, vertejai, veterinarai ir t. t., taip pat namų šeimininkès. Labai plati ir amžiaus skalè: jauniausia dalyvẻ buvo 11-os metų klaipėdietẻ rusakalbẻ moksleivé, o vyriausi - septintąią dešimtị bebaigiantys pensininkai. Jauniausieji kursantai priimami išimties tvarka, čia jie mokosi kartu su suaugusiaisiais, nes specialiu grupių ar kursų vaikams kol kas neorganizuojama.

Toliau pateikiama KU lietuvių kalbos ir kultūros intensyvių vasaros / žiemos kursų dalyvių statistika pagal jų kilmės šalis (duomenys nuo $2002 \mathrm{~m}$. vasaros iki 2020 m. žiemos imtinai, iš viso 18 vasaros kursų ir 6 žiemos kursai). Žinoma, santykis tarp dalyvių skaičiaus iš konkrečių šalių per minimą laikotarpi keitėsi. Tas pokytis apima visą kompleksą veiksnių, aplinkybių ir galètų būti įdomi tema tyrimui.

Lietuvių kalbos kursų dalyvių tikslai, motyvai įvairūs. Pagal tai galima išskirti kelias KU lietuvių kalbos kursų dalyvių kategorijas:

1. Užsienio aukštųjų mokyklų studentai, dèstytojai, tyrèjai. Lietuvių kalba susijusi su ju studiju / mokslo sritimi arba tiesiog pasinaudojama galimybe dalyvauti minėtoje ŠMPF valstybinių stipendijų programa (ar kitomis finansavimo programomis), norint pažinti naują šalì, jos kalbą ir kultūrą. 


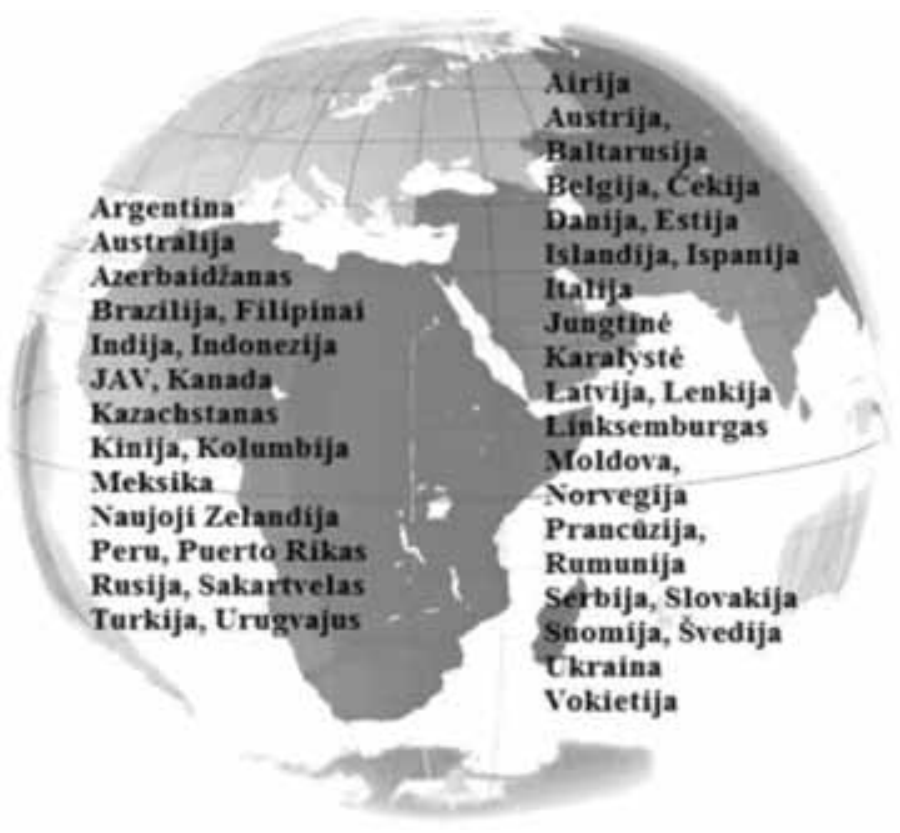

3 pav. Šalys, kurių piliečiai mokèsi KU lietuvių kalbos kursuose

Ypač daug kursantų buvo atvykę / atvyksta iš šių užsienio aukštųjų mokyklų: (iki 2014 m.) Baltijos federalinio Imanuelio Kanto universiteto Kaliningrade; Krokuvos Jogailaičių universiteto; Maskvos valstybinio M. V. Lomonosovo universiteto, Rusijos valstybinio humanitarinių mokslų universiteto; Ukrainoje - iš ìvairių universitetų.

\section{Lietuvių kilmès užsieniečiai}

Šių dviejų kategorijų kursantai pastaruoju metu sudaro 2/3 besimokančiųjų Vasaros / Žiemos akademijoje ir apie 90 proc. jų atvyksta pagal minètą Valstybinių stipendijų programą. Iš šių stipendijas gavusių asmenų lietuvių kilmès užsieniečių būna apie penktadalį. Konkurso sąlygas ir kvotų skaičių nustato ŠMPF. Iki 2020 m. nebuvo ribojamas leidžiamų dalyvauti stipendijų konkurse kartų skaičius, todèl iš KU Vasaros / Žiemos akademijų dalyvių apie 10 yra čia dalyvavę tris ir daugiau kartų.

\section{Lietuvių tautybès asmenų sutuoktiniai / partneriai}

4. Užsieniečiai, apsigyvenę Lietuvoje darbo ar kitais tikslais, ir jų šeimos nariai. Čia dar būtų galima išskirti asmenis, atvykusius dèl konkrečių gerų darbo pasiūlymų, ir asmenis, emigruojančius iš savo šalių dèl tam tikrų politinių ar ekonominių priežasčių ir siekiančius įsitvirtinti Lietuvoje (arba vẻliau išvykti i kitas šalis). Pastaraisiais keleriais metais ypač gausėja Ukrainos ir Rusijos piliečių. 


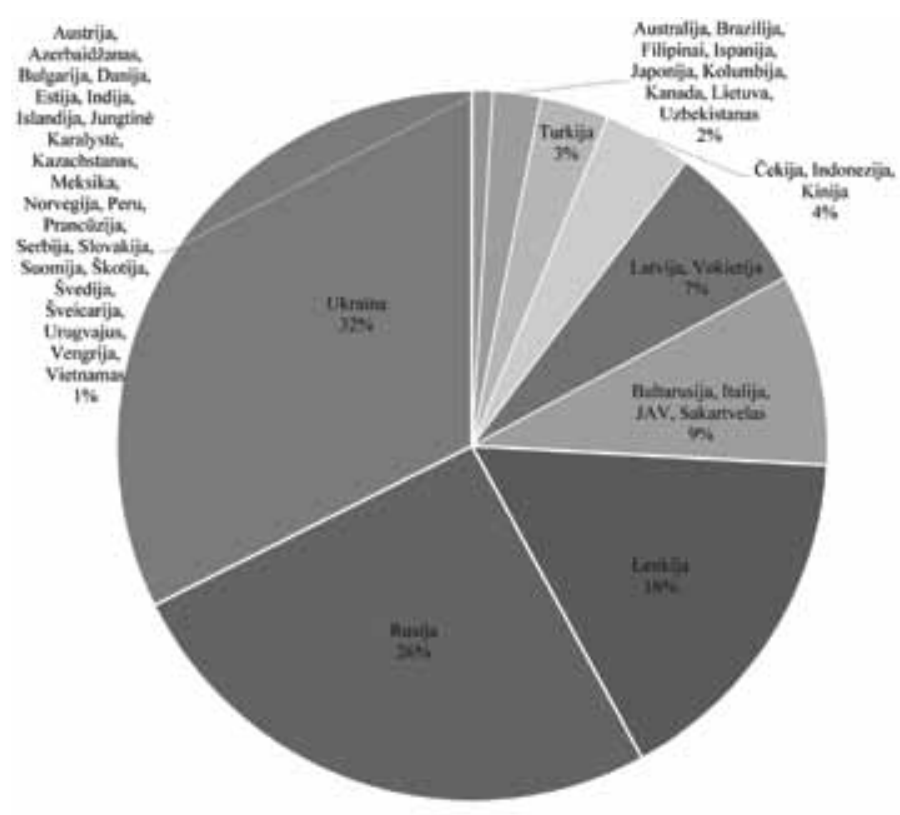

4 pav. KU lietuvių kalbos vasaros ir žiemos kursų dalyvių statistika pagal šalis (nuo $2002 \mathrm{~m}$. vasaros iki $2020 \mathrm{~m}$. žiemos)

Todèl norinčiųių mokytis lietuvių kalbos skaičius ir tautinė sudètis gana aiškiai rodo imigracijos Lietuvoje tendencijas.

Kiti. Šiai lietuvių kalbos kursų dalyvių kategorijai būdinga itin didelè motyvų įvairovè: pavyzdžiui, estas nori gerai pramokti artimiausių kaimynų - Latvijos ir Lietuvos - kalbas; kanadietis nori aplankyti vietą, kurioje gyveno jo senelis (ne lietuvis), nors namo ten ir nebėra; rusaitė nori išmokti kalbą, nes ne kartą atostogavo Lietuvoje ir susižavejo šiuo kraštu, ir daug kitokių atvejų.

Iš semestro kursuose besimokančiųjų lietuvių kalbos 99 proc. yra gyvenantys / laikinai apsigyvenę / apsistoję Lietuvoje asmenys (o ne specialiai atvykstantys ị kursus).

Statistiniai duomenys apie KU lietuvių kalbos kursų dalyvius gana akivaizdžiai atspindi demografines tendencijas Lietuvoje, procesus kai kuriose užsienio valstybèse ir kitas aplinkybes - tarp jų ir lietuvių kalbos mokymui skiriamą dèmesi valstybès mastu. Lietuvos Respublikos Seimo 2018 m. birželio 27 d. nutarime Nr. XIII-1318 „Dèl valstybinès kalbos politikos 2018-2022 m. gairiu“ analizuojamas ,lietuvių kalbos mokymas ir mokymasis išeivijoje ir reemigracijoje“ (LR Seimo nutarimas, 11), pabrěžiamas būtinumas ,skatinti lietuvių kalbos mokymą (mokymąsi) užsienyje“, tuo tikslu teikti materialinę ir metodinę paramą užsienyje veikiančioms lituanistinėms mokykloms ir centrams, „kuriuose 
lietuvių kalbos mokosi užsienio šalių piliečiai, [...] skatinti lietuvių kalbos mokymą (mokymąsi) gretimose šalyse" (ten pat, 15).

Lietuvių kilmès užsieniečių skaičius Vasaros / Žiemos akademijoje pamažu, bet nuosekliai auga; žmonès atvyksta ne tik pagal minėtąią stipendijų programą, bet ir savo lèšomis. Šioms besimokančiųju grupèms skiriamas papildomas dèmesys, pavyzdžiui, organizuojamas lietuvybės vakaras; ji rengia KU lietuvių kalbos kursų organizatorių komandos bičiulis, aktyvus Pasaulio lietuvių bendruomenès (PLB) narys Aleksas Eugenijus Kulvietis Suarezas, gimęs Kolumbijoje. Jis atvyko ì pirmąją KU vasaros mokyklą 2002 m. mokedamas tik keletą žodžių lietuviškai ir puoselėdamas svajonę pamatyti senelio tėvynę. Apsigyvenęs Lietuvoje, po kurio laiko jis tapo lietuvių kalbos kursų dėstytojų ir organizatorių bendradarbiu.

Kaip minėta, nemažai kursų dalyvių mokosi ne vieneriuose KU lietuvių kalbos kursuose; jie tęsia mokymąsi nuosekliai pereidami nuo žemesnio į vis aukštesnius kalbos mokejjimo lygius. Tarp tokių yra ir atvykstančių užsieniečių, ypač per jau minètą Valstybiniu stipendiju lietuviu kalbos ir kultūros vasaros / žiemos kursams programą. Pavyzdžiui, tokių vadinamųjų kursų senbuvių 2019 m. Vasaros akademijoje buvo beveik 40 proc. Tai labai didelis skaičius. Vietiniu gyventojų dalyvavimo keleriuose kursuose iš eilès motyvai lengvai nuspejjami, tačiau kas paskatina specialiai mokytis lietuvių kalbos į Lietuvą atvykstančius žmones vèl grịžti į Klaipėdos universitetą? Kadangi visų kursų dalyvių atsiliepimai yra kruopščiai renkami ir analizuojami, galima apibendrinti viso ciklo - Žiemos akademijos, pavasario semestro, Vasaros akademijos ir rudens semestro kursų duomenis. Išskirtini šie pagrindiniai kursų dalyvių nurodyti pritraukiantys veiksniai:

- dèstytojuc darbas;

- plati ir intensyvi kultūrinė-pažintinè programa (Vasaros / Žiemos akademijoje);

- organizatorių darbas, bendra atmosfera.

Déstytojai ir jų darbo ypatumai, kursuc organizatoriuc veikla

„Our teachers at Klaipeda University are everything that is good about the world, truly. " (Rasa Kabaila, Australija)

Klaipėdos universitete lietuvių kalbos kaip L2 moko ir mokè lituanistai, igiję šią specializaciją savo praktiniu darbu, taip pat savarankiškai mokydamiesi, bendradarbiaudami su kolegomis Lietuvoje ir užsienyje, stebėdami kitų kalbų,

7 Mūsų dèstytojai Klaipèdos universitete - tai visa, kas yra gero pasaulyje. 
turinčių ilgas kitakalbių mokymo tradicijas, mokymą užsienio aukštosiose mokyklose.

Neteko užfiksuoti konkrečių faktų, jog po Lietuvos nepriklausomybės atgavimo ar sovietiniu laikotarpiu būtų buvę rengiami lietuvių kalbos kaip negimtosios mokymo specialistai. Tiesa, užuominų apie tai esama (Buivydienè, Žukienė 2006), tačiau tvirtai tą teigti būtų galima tik atlikus tyrimą. Dabar ši lituanistinių studijų sritis įtraukta - bet tik kaip vienas iš studijų dalyku - i VDU bakalauro studijuc programą Lietuvių filologija ir leidyba; dalykas vadinasi Lietuvių kalbos, kaip svetimosios, destymo metodika (LFL4011) ir jo apimtis 5 studiju kreditai. VU FF Lituanistinių studijų katedra kaip taikomojo pobūdžio dalyką siūlo svetimųjų kalbų dėstymo metodiką (http://www.lsk.flf.vu.lt/lt/katedra/apie-mus/veikla/).

Žvilgtelèjus ị kai kurių kitų kalbų kaip L2 mokymo situaciją, matyti, jog norint tapti akredituotu mokytoju privaloma speciali kvalifikacija; jos pobūdis dar priklauso ir nuo tikslinės grupès, t. y. būsimų mokinių. Pavyzdžiui, tapti anglu kalbos kaip L2 mokytoju galima iggijus kuri nors iš ESL (anglų kaip užsienio kalba) sertifikatų: vienas iš trumpiausių TEFL kursų yra 120 valandų. Ispanų kalbos kaip negimtosios (ELE) diplomas gaunamas baigus ELE mokymo magistro studijų programą. Norintiems dèstyti rusų kalbą kaip L2 būtina arba turèti filologijos krypties ne mažesnị kaip magistro laipsnio atitikmenį ir pagal programą būti studijavus rusų kalbos kaip negimtosios dẻstymo metodiką, arba baigti trumpalaikius kursus (panašiai kaip anglų kalbos atveju).

Antras pabrèžtinas dalykas, - kad po Lietuvos nepriklausomybės atgavimo lietuvių kalbos pradejję mokytis užsieniečiai buvo įvairių tautybių, vadinasi, kalbantys skirtingomis gimtosiomis ir išmoktomis kalbomis. Palyginti su sovietiniais laikais, kai lietuvių kalbos mokymas buvo labiau orientuotas ị rusų kalbą, kurios gramatine sistema iš esmès panaši i lietuvių, nepriklausomybės laikotarpio situacija tapo daug sudėtingesnè, nes atsirado besimokančiųjų, kurių gimtoji kalba netgi nepriklausė indoeuropiečių kalbų šeimai. Taigi kilo būtinybẻ „sukurti sistemą, kaip mokyti lietuvių kalbos kaip svetimosios, kartu ugdant komunikacinius įgūdžius ir įvertinant Lietuvos sociokultūrinị kontekstą, t. y. supažindinant su tautos kultūra ir jos sociokultūrinès aplinkos sąlygomis“ (Buivydienè, Žukienė 2006). Taigi akivaizdu, kad lietuvių kalbos kaip L2 pradžia buvo sudètinga, lituanistai mokẻ ir mokėsi patys, vykdẻ tyrimus, rengẻ metodinę medžiagą.

KU lietuvių kalbos kursuose iš viso yra dirbę 19 kalbos dèstytojų: kai kurie visus 20 metų, keli - tik epizodiškai. Daugelis jų yra KU dèstytojai / darbuotojai. Galima teigti, jog visi jie yra igiję praktinę konkrečią specializaciją šioje srityje: prof. Dalia Pakalniškienè, doc. dr. Vaida Drukteinytė - mokymas aukščiausio kalbos mokejimo lygio grupèse; doc. dr. Asta Balčiūnienè, Kristina Kulvietiené - darbas su B1-B2 lygio kursantais; dr. Kristina Blockytė-Naujo- 
kè - mokančiųju lygio komunikaciniai kursai. Ivvairių lygiu grupes imasi mokyti dr. Daiva Pagojiené, nes ji dirba ir su akademinès sistemos universiteto studentais užsieniečiais; Jūratė Derukaitė, Virginija Jurgaitytė, Dalia Želvytė-Mockuvienė, Lilija Zoločevskaja-Putrienè dirba su pradedančiųjų lygių besimokančiaisiais - šioms dėstytojoms praverčia ir i̇gyta užsienio kalbos specializacija. Taip pat yra dirbę prof. Albinas Drukteinis, doc. dr. Algirdas Ruškys, Aušra Lemberger (Trumpickaitè), Vitalija Kapsevičienè, doc. dr. Laimutė Servaitė (pagrindinis išsilavinimas - anglų filologija; ši specialistė moke ES institucijų vertejjus ir kt.), doc. dr. Jūratė Lubienè. Pastaruosius porą metų KU lietuvių kalbos kaip L2 dèstytoju gretas labai sẻkmingai papildè dvi patyrusios mokytojos lituanistės mokytoja eksperte Vilma Dulevičienè ir mokytoja metodininkè, scenos menu atlikèja Vilija Šeputiené.

Šalia kalbos mokymo ịvairių sričių kultūros paskaitas Vasaros / Žiemos akademijoje veda ir kiti specialistai.

Daugiausia kalbos dẻstytoju vienu metu yra dirbę $2018 \mathrm{~m}$. Vasaros akademijoje - net 10 lituanistų. Dèl didelio krūvio daugumos grupių mokymo kursą dèstytojos dalijasi pusiau. Pasitelkiamos ir dėstytojų asistentès. Šị darbą ne kartą dirbo KU filologijos programų studijų praktikantès, ịgijusios unikalios patirties.

Trumpai užsimenant apie mokymo metodikos dalykus, atkreiptinas demesys $\mathfrak{i}$ tai, jog sẻkminga praktika yra integruotos grupès, kai kartu mokosi ir atvykstantys, ir vietiniai kursų dalyviai, ir KU studentai užsieniečiai; tokia besimokančiųju įvairovė vienoje grupejje - didelis metodinis privalumas, nors kartu kyla ir tam tikrų papildomų didaktinių, psichologinių ar sociokultūrinių niuansų. Kalbos pamokose, atsižvelgiant ị kalbos mokejjimo lygį, taikomi i̇vairūs metodai, tačiau daugiausia dèmesio skiriama komunikacijai. Vasaros / Žiemos akademijoje kalbos mokymo turinys glaudžiai siejamas su kultūrine programa ir kalbos praktika. Būna ir išvykstamųjų praktikų, pavyzdžiui, konkrečios leksikos ittvirtinimo tikslais.

Iš mokymo aktualijų pirmiausia reikètų pabrèžti tai, kad aukštesnių negu pradedančiųjų lygio grupèse dažnai pasitaiko tam tikros diferenciacijos; susirinkę kursų dalyviai turi skirtingą kalbos mokymosi patirtį, išsilavinimą, užsièmimą, būna skirtingo amžiaus ir gebejjimų; taigi dèstytojas kartais turi ir subtiliai diferencijuoti mokymą, ir gebėti visus integruoti bendrai veiklai. Didelis dèmesys skiriamas psichologiniam mikroklimatui, sociokultūriniam aspektui. Dėstytoju pastangas pastebi ir įvertina kursų dalyviai. „Nesvarbu, su kokio lygio lietuvių kalbos žiniomis susiburia kursų dalyviai - nuo 11 iki 74 metų amžiaus; per keletą dienų dėstytojai sugeba pasiekti, jog pamokos taptų nenuobodžios stipresniesiems ir ne per sudetingos kitiems, taigi mes tampame darnia komanda ir 
kiekvienas siekiame pažangos“, - taip savo atsiliepime parašė vokietis Helmutas Pelmas, KU lietuvių kalbos kursuose dalyvavęs daugelị kartų.

Vis dar išlieka aktuali mokomosios medžiagos problema. Nors, kaip minèta straipsnio pradžioje, mokomųju priemoniu išleista ir tebeleidžiama gausiai, vis dèlto daug medžiagos, ypač $\mathrm{C}$ lygio (kalbos mokejjimo) grupėms, tenka kurti patiems. Kalbant apie C lygio medžiagą, reikia atsižvelgti ir ị tai, kad KU kursuose savo žinias toliau tobulina nemažai jau buvusiu kursantų. Iš kursų dėstytojų parengtų mokomųjų priemonių paminètina D. Pagojienės ir J. Derukaitės „Aš kalbu lietuviškai A1(1)“: metodinè priemonė (Klaipėdos universiteto leidykla, 2017) bei V. Jurgaitytės ir J. Derukaitės laikmenos formato dauginama ir nuolat atnaujinama mokomoji priemonė „Labas“, ypač patogi mokymui(si) tuo, jog visi tekstai išversti (pagal sugestopedijos metodą atlikus kiek įmanoma labiau pažodinị vertimą) į anglų ir (kitoje mokomosios priemonès versijoje) ị rusų kalbas. Kitų dẻstytoju parengta originali medžiaga, ypač komunikacinè, tikètina, kada nors irgi taps prieinama ne tik KU lietuviu kalbos kursų dalyviams.

KU Vasaros / Žiemos akademijos veikloje labai svarbus ir mentorių darbas. Jị atlieka vienas ar keli jauni žmonės, kursų organizatorių komandos nariai. Dar prieš prasidedant kursams mentoriai konsultuoja būsimuosius kursantus įvairiais aktualiais klausimais (pavyzdžiui, dèl atvykimo, gyvenimo Lietuvoje ypatumų, kursų programos), prireikus pasitinka atvykstančius į kursus užsieniečius, padeda rengti ir vesti kultūrinès kursų programos renginius. Mentorystės veikla yra svarus indèlis, kad kursų mėnuo visiems jų dalyviams būtų kuo sklandesnis. Keletą metų šị darbą sèkmingai dirbo Tomas Lenkauskas (tuo metu - KU doktorantas), Daumantas Pagojus (mentoriumi dirbo ir būdamas gimnazijos moksleiviu, ir jau studijuodamas). Daug padejjo ir Gabija Pagojūtè (tuo metu - gimnazijos moksleivè). Mentorèmis dirbo ir KU studentès, KU Vasaros akademijoje atlikdamos savo studijų praktiką.

Prie kursų veiklos jau prisideda ir kai kurie kursantai, pasiekę aukštą lietuvių kalbos mokejjimo lygị, ir tai jiems yra galimybe igyti papildomos kalbinès praktikos. Pavyzdžiui, germanų filologijos specialistė dr. Nadia Sadovnyk-Chuchvaha iš Černivcų nacionalinio universiteto (Ukraina) jau ne kartą sèkmingai vertejjavo žodžiu iš lietuvių ị anglų kalbą KU Vasaros / Žiemos akademijos renginiuose.

Kultūrinè-pažintinè programa - integrali lietuvių kalbos ir kultūros kursuc dalis

Bet kurios kalbos mokymasis neatsiejamas nuo ja kalbančios tautos, šalies pažinimo, pradedant jau pačia pirmąja pamoka: kaip sveikintis, kokia įvardžio forma kreiptis etc. Toliau - gyvenimo būdo, tradicijų, bendravimo ypatumų 


\section{9 m. lietuvių kalbos ir kultūros vasaros akademijos kultūrinè programa}

\begin{tabular}{|c|c|}
\hline $\begin{array}{l}\text { Iki kursų } \\
\text { pradžios }\end{array}$ & $\begin{array}{l}\text { Liepos 11-14 d. tarptautinio folkloro festivalio „Lauksnos“ renginiai. Rekomenduojame! } \\
\text { https://www.lauksnos.1t/en/ }\end{array}$ \\
\hline $\begin{array}{l}\text { Liepos } \\
12 \mathrm{~d} .\end{array}$ & Kursų atidarymo šventė KU Mažojoje auloje (Herkaus Manto g. 84) \\
\hline $07-14$ & Išvyka ị Neringą, Kuršių nerijos nacionalinį parką \\
\hline $07-15$ & Ekskursija po Klaipėdos senamiestị (angliškai ir lietuviškai) \\
\hline $07-17$ & Draugystès vakaronė \\
\hline $\begin{array}{l}\text { Liepos } \\
19-21\end{array}$ & $\begin{array}{l}\text { Savaitgalio kelionė po Lietuvą susipažistant su ịvairiais regionais ir aplankant visas Lietuvos sostines - } \\
\text { buvusias ir dabartinę: Kauną, Vilnių, Trakus ir Kernavę. }\end{array}$ \\
\hline $07-22$ & Kultūros paskaita. Šiuolaikinès lietuvių literatūros apžvalga (lietuviškai) \\
\hline 07-23 & Kultūros paskaitos su KU istoriku-archeologu (atskirai angliškai ir lietuviškai) \\
\hline 07-24 & Kultūros paskaita baltistikos temomis (lietuviškai) \\
\hline $07-25$ & $\begin{array}{l}\text { Kultūrinė veikla. Grojimas lietuvių liaudies instrumentais } \\
\text { Lietuviška popietė fakulteto sode su ansambliu „Kuršių ainių“ muzikantais }\end{array}$ \\
\hline 07-26 & Dalyvavimas iškilmingoje Jūros šventès eisenoje su Klaipėdos universiteto bendruomene \\
\hline $\begin{array}{l}\text { Liepos 26- } \\
28\end{array}$ & $\begin{array}{l}\text { Laukiamiausias Klaipėdos renginys - Jūros šventè } 2019 \text { (dalyvavimas savarankiškai). } \\
\text { (http://www.jurossvente.lt/). }\end{array}$ \\
\hline 07-30 & Viešnagė lietuvių šeimoje. Bus vykstama ị kelias skirtingas vietas. \\
\hline $\begin{array}{l}\text { Rugpjūčio } \\
1 \mathrm{~d} .\end{array}$ & $\begin{array}{l}\text { Klaipėdos miesto gimtadienio šventė senamiestyje. Inscenizuoti šviečiamieji-pramoginiai renginiai apie } \\
\text { viduramžius. }\end{array}$ \\
\hline $\begin{array}{l}\text { Rugpjūčio } \\
4-5\end{array}$ & $\begin{array}{l}\text { Ekskursija po Žemaitiją su nakvyne kaimo turizmo sodyboje. Vakarienė ir pusryčiai - lietuvių } \\
\text { nacionalinè virtuvè. }\end{array}$ \\
\hline $08-07$ & Pažintinė išvyka i Kuršiu marias laivu VENUS su gidu \\
\hline 08-08 & Atsisveikinimo popietė universiteto sode. Lietuvių liaudies dainos ir šokiai su muzikantais. \\
\hline
\end{tabular}

pažinimas ir su tuo susijusios leksikos, gramatikos, sintaksès mokymasis. Šis kultūrinio pažinimo elementas nuosekliai siejamas su gramatine medžiaga mokomosiose priemonèse. Tačiau kalbų mokymo kursuose tam skiriamas ir papildomas dèmesys. Visuose KU lietuvių kalbos kursuose šalia kalbos pamoku organizuojamos teminès vakaronės, išvykos, kitokie renginiai. Tačiau plačiausia kultūrinè programa yra siūloma Vasaros / Žiemos akademijoje, nes didžiausia dalis klausytojų - specialiai suvažiavę i kursus iš viso pasaulio, ir jiems aktualu per mènesi spèti kuo daugiau pamatyti, kuo geriau pažinti Lietuvą. Jau minèta, kad kultūrinei-pažintinei programai Vasaros / Žiemos akademijoje skiriama maždaug 40 papildomų valandų: tai seminarai (istorijos, kalbotyros, literatūros, muzikinio folkloro temomis), išvykos, ekskursijos ir kartu daug kalbos praktikos tų veiklų metu.

Išanalizavus beveik dviejų dešimtmečių KU vasaros ir žiemos intensyvių kursų dalyvių rašytinius ir žodinius atsiliepimus bei rekomendacijas, matyti, jog šiuo 
klausimu nuomonė vieninga: KU siūloma kultūrinė programa yra maksimaliai plati ir intensyvi. Ne vienam kursų dalyviui tai buvęs lemiamas universiteto pasirinkimo veiksnys. Pavyzdžiui, 2019 m. vasaros akademijos kultūrinė programa.

Vis dẻlto kad ir kokia būtų gera ir organizaciniu požiūriu suderinta kultūrinè programa, joje kiekvieną kartą privalu padaryti tam tikrų pakeitimų, įtraukti naujų renginių, kultūros paskaitų, lankytinų objektų, keisti ekskursijų gidus ir vedimo formas: kaip minèta, KU lietuvių kalbos kursuose (aukštesniųjų lygiu grupėse) visada dalyvauja buvusių kursantų; ypač daug ju būna Vasaros akademijoje - beveik trečdalis dalyvių.

Pabrēžtina, jog kultūrinejje kursų programoje dalyvauja ir kalbos pamokų dèstytojai (kartais jie veda renginius), ir tai yra didelis privalumas: daugiau galimybių kalbos praktikai, stiprẻja ryšys tarp mokytojų ir mokinių, vyksta tarpkultūrinè komunikacija, praturtinanti žiniomis ir mokinius, ir mokytojus.

Kursuose ne tik išmokstama kalbos: adaptacija ir socializacija

„Kiekvienq kartq atvykęs i Klaipèdą, mūsų kursuose tikrai jaučiuosi kaip šeimoje." Giorgi Janiashvili (Sakartvelas)

Pažvelgus į 44 šalių sąrašą (iš tų šaliu per 20 metų buvo arba yra atvykę KU lietuvių kalbos kursų dalyviai), nesunku įsivaizduoti, kad kartu su kalbos mokymu ir kursantams, ir dėstytojams reikejjo taip pat išmokti ir kitų dalykų - gilesnio vieni kitų kultūrų pažinimo, supratimo, tolerancijos. Reikia priprasti prie to, kad kartais skirtingai suvokiamas požiūris ì mokymąsi, atsakomybę, netgi punktualumą. Mokytis lietuvių kalbos atvyksta ir žmonių, visiškai nepažįstančių lietuvių gyvenimo būdo, nepratusiu prie europietiško maisto arba, pavyzdžiui, niekada nebuvusių tikrame miške ${ }^{8}$. Dèl kultūrinių, politinių, ekonominių, religinių skirtumų, dẻl aplink vykstančiu ir neišvengiamai atgarsị turinčiu politinių ịvykių ar procesų, natūralu, kyla įvairių kolizijų. Bendros kursų atmosferos kūrimas - atsakingas ir subtilus visos kursų organizatorių komandos darbas. Galima teigti, jog šis darbas vyksta labai sẻkmingai: KU lietuviu kalbos kursų dalyviai ir dèstytojai - miniatiūrinè įvairiatautė bendruomenė - pavyzdys, kaip kartu susirinkę labai skirtingi žmonès gali būti kartu, užsiimti bendra veikla ir siekti bendrų tikslų, netgi tapti draugais.

Vietiniams kitataučiams lietuvių kalbos mokymasis kursuose turi papildomų veiksnių. „Dažnai atvykę gyventi į Lietuvą kitataučiai jaučia socialinę atskirtị - kalbos barjeras, kultūriniai skirtumai atriboja nuo visuomenès, kurioje jie

8 Kartą per ekskursiją merginos iš Kinijos netgi glostė žolę. 
gyvena, patiriamas kultūrinis šokas. [...] Kursuose susipažįstama su panašaus likimo kursantais, susibičiuliaujama, todèl keičiasi atvykusiųjų nuotaika, gyvenimo Lietuvoje kokybė“ (Pagojienė 2017). Todèl per KU lietuvių kalbos kursų veiklą organizatoriai stengiasi suburti tokius žmones. Nuo $2014 \mathrm{~m}$. sèkmingai gyvuoja socialinejje paskyroje Facebook įkurtas virtualusis lietuvių kalbos kitataučiams klubas Amici Lituanici, siejantis arti šimto narių; taip palaikomas bendravimas su kursų alumnais, mezgasi bičiulystès ir bendradarbiavimo ryšiai; bendravimo pagrindu išlieka lietuvių kalba, kultūra, Lietuva.

Su nemaža dalimi alumnų šiandien bendraujama tik lietuviškai, - o juk ne vienas iš jų lietuvių kalbos KU pradėjo mokytis nuo ABC. „Išmokti kalbèti lietuviškai - tai nemenkas iššūkis dažnam kitakalbiui. Besimokančiųju pastangos, bendraminčių palaikymas, dėstytojų kantrybė ir sumanumas, palankus psichologinis klimatas suteikia galimybę prabilti viena iš seniausių išlikusių indoeuropiečių kalbų, pažvelgti i pasauli šios senos tautos akimis bei tapti jos dalimi““ (Pagojienė 2017). To pasiekẻ daugybė KU lietuvių kalbos kursų dalyvių.

\section{Lietuviuc kalbos kursai ir bendradarbiavimo plètra}

Kaip minèta, iš buvusių KU lietuvių kalbos kursų dalyvių ne vienas jau moko lietuvių kalbos savo šalyse. Nemažai alumnų tampa aktyviais lietuvių kalbos ir kultūros skleidèjais, tarptautinių draugijų nariais. Pavyzdžiui, Ukrainos ir Lietuvos draugija Kijeve; ten sklaidos veikloje aktyviai dalyvauja jau keletą metu KU kursuose nuolat besimokantys Jurijus Samsonas, Bohdanas Malanchukas. Daug lituanistinès veiklos vyksta Maskvoje, ją remia LR ambasada; $2020 \mathrm{~m}$. liepos mėnesi diplomu su pagyrimu socialinès antropologijos magistrantūros studijas Maskvoje baigė kelių KU kursų alumnė Amina Shulpina, apgynusi su lietuvių kalbos specializacija susijusį baigiamąii darbą, kuriam medžiagą rinko studijuodama Lietuvoje; prieš gynimą dar vedè vebinarą Lietuva ir lietuviai, tokie, kokiu mes ju nemateme: itraukto stebejimo patyrimas; abiejuose renginiuose dalyvavo lietuviu diplomatų. Su lietuvių kalba ir kultūra susijusioje veikloje Maskvoje dalyvauja ne viena KU lietuvių kalbos kursų alumnè: dr. Daria Ter-Minasova, lingvistikos studentė Svetlana Kukushkina.

Nemažas KU lietuvių kalbos kursų dalyvių indèlis ir ị bendradarbiavimo ryšius tarp universitetų, yra kuriamos bendros studijų programos; čia reikia paminèti KU kursų dalyvị dr. Artemą Petryką (Ukraina), Lietuvos istorijos tyrimų centro įkūrèją Chersono universitete, aktyvų žinių apie Lietuvą skleidèją Ukrainoje; jis yra ir KU Baltijos regiono istorijos ir archeologijos instituto (BRIAI) bendradarbis. Bendradarbiauja filologai, taip pat ir kitų krypčių tyrejai. Pavyzdžiui, KU lietuvių kalbos kursuose ne kartą kalbos žinias tobulinusios tyrèjos iš 
Maskvos dr. Marina Valentsova ir dr. Natalia Petrova bendradarbiauja mokslo srityje su KU filologais.

Taip pat paminètina, jog KU lietuvių kalbos kursų dalyviai, per kursus geriau susipažinę su KU, tampa ir laipsnio ar dalinių studijų studentais; pavyzdžiui, minètojo BRIAI vienas iš doktorantų šiuo metu yra italas Flaviano Bertaina, daug kartų ne tik dalyvavęs KU lietuvių kalbos kursuose, bet ir pats dirbęs kursų rengejuc komandoje.

KU lietuvių kalbos kursų vertinimas ir pripažinimas

Per visus beveik dvidešimt veiklos metų KU lietuvių kalbos kursų organizatoriai atidžiai analizavo pasiektus mokymo rezultatus, kursų dalyviu atsiliepimus ir rekomendacijas. Galima sakyti, kad šie dalyviai, ypač tie, kurie dalyvavo KU kursuose daug kartų, padejjo kurti savąją nuoseklią kalbos mokymo sistemą. Žinoma, patenkinti visų kursantų lūkesčių neįmanoma, nes skiriasi ne tik kursų dalyvių tautybè, bet ir kai kurių iš jų ịsivaizdavimas, kokie turi būti kalbos kursai, ko ir kaip reikia mokytis ir išmokti.

Be puikių ir nuoširdžių atsiliepimų, per daugeli metų surinktų iš KU lietuvių kalbos kursų dalyvių, galima paminèti ir oficialius įvertinimo faktus. $2015 \mathrm{~m}$. kursų vadovei įteikta ŠMPF padèka už didžiausią pritrauktų KU Lietuvių kalbos vasaros kursų užsieniečiams dalyvių skaičių (pagal šio fondo administruojamą valstybinių stipendijų programą). 2018 m., minint 20-ąsias ŠMPF veiklos metines, buvo apdovanoti geriausi Lietuvos 2018-ųjų švietimo mainų projektai; Klaipèdos universitetui įteikta padèka „už ilgametį lietuvių kalbos ir kultūros puoselejimą tarptautiniu mastu, rengiant lietuvių kalbos ir kultūros kursus užsieniečiams".

Lietuvių kalbos kursų veiklą rẻmé visi buvę KU rektoriai, šiuo metu prof. Artūras Razbadauskas. Per visą kursų veiklos laikotarpị šiomis lituanistinèmis studijomis rūpinasi ir globoja SHMF dekanas prof. Rimantas Balsys. Savo ruožtu užsieniečių mokymo veikla gražiai reprezentuoja universitetą ir Lietuvoje, ir visame pasaulyje.

Per 2019 m. Vasaros akademijos baigimo šventę kursų dalyviams buvo pasiūlyta parašyti ką nors ant fakulteto salès, laukiančios renovacijos, sienų. Tie užrašai įamžinti ilgamečio lietuvių kalbos kursų bendradarbio Sauliaus Pagojaus nuotraukose. Štai keletas užrašų (kalba netaisyta, vardų palikta tik pirmoji raidè): „Ačiū už įspūdžius! A.“; „Viskas labai smagu. Aš myliu. Ačiū iš Sakartvelo. S.S.D“; „Džiaugiuosi geriausiąja visų laikų akademija! F.“; „Ačiū už akademiją! Buvo labai smagu mokytis Klaipėdos universitete“; „Iš Ukrainos su meile! N.“; „N.: Klaipeda Mantul! From Indonesia!“; „Ačiū, mano dèstytoja!“; ,, Jūs 
nuostabūs!“; „Ačiū, Klaipėda, už mūsų puikią vasarą!“; „Saya Cinta Lithuania (I love Lithuania) - L.“; „Ačiū už puikią patirtį ir draugystes“; „Iki pasimatymo!“; „Grazie!“; , „KÖSZÖNÖM! IKI! E. P.“.

\section{Išva dos}

Klaipèdos universiteto (KU) vykdomi neformalieji lietuvių kalbos kaip negimtosios (L2) mokymai organizuojami atskirai nuo universiteto laipsnio studiju sistemos. Šių mokymų ciklą sudaro semestro kursai ir intensyvūs vasaros bei žiemos kursai - Lietuvių kalbos ir kultūros vasaros / žiemos akademija. KU lietuvių kalbos kaip L2 mokymo sistema pasižymi tęstinumu ir lankstumu.

Šios KU lituanistinès studijos, nuo kurių pradžios jau prabėgo du dešimtmečiai, o veiklos apimtis išaugo apie dešimt kartų, yra kompleksinis reiškinys, auganti ir evoliucionuojanti sistema. Taigi perspektyvos priklauso nuo kiekvieno šios sistemos komponento ir kartu nuo sklandaus ju sąryšio.

Per visą veiklos laikotarpị lietuvių kalbos mokymuose dalyvavo arti 3000 žmonių. Gausiausio dalyvių skaičiaus sulaukiama Vasaros akademijoje (apie 60-70). Dauguma kitataučiai, tačiau tarp jų daugejja ir lietuvių kilmès asmenų. KU lietuvių kalbos kursų dalyviai - tai asmenys, sumokantys nustatytą kursų įmoką, ir asmenys, kurių lituanistinès studijos finansuojamos projektų lèšomis. Siekiant suteikti norintiesiems daugiau galimybių mokytis lietuvių kalbos, organizatoriams reikia plèsti projektinę veiklą, ieškoti naujų finansavimo galimybių.

KU kursų dalyviai yra įvairaus amžiaus pilnamečiai asmenys. Nepilnamečiai gali mokytis tik išskirtiniais atvejais. Tačiau ateityje būtu galima pasvarstyti apie vaikų mokymo galimybę, nes tikètinai daugès grižtančiu iš emigracijos šeimų. Be to, Klaipèdos universitete vykdomos pedagoginès studijos, taigi atsirastų ir reikalingų konsultantų, specialistų.

Lietuvių kalbos kaip L2 mokymas - gana nauja lietuviu kalbos mokymo(si) patirtis. Šis poreikis ėmė ypač sparčiai augti Lietuvai tapus Europos Sąungos nare. Lietuvių kalbos kaip L2 mokytojais, dėstytojais tapo lituanistai, igydami šią specializaciją praktiniu darbu, teorinių žinių kaupimu, mokslo tyrimais. KU lietuvių kalbos kursuose dirbantys dèstytojai nuolat mokosi, stebi kolegų darbą Lietuvoje ir užsienyje, dalijasi patirtimi. Dėstytojų kvalifikacijos siekiamybė, kad jie galètų mokyti lietuvių kalbos visais lygiais pagal Bendruosius Europos kalbų metmenis (BEKM).

Lietuvių kalbos kaip L2 mokomosios medžiagos gana gausu, tačiau vis tebejaučiama tam tikrų trūkumų. Daug originalios medžiagos (ypač komunikacinès) tenka kurti $\mathrm{C}$ lygio grupių besimokantiesiems. Taigi darbas kaupiant, rengiant ir sisteminant mokomąją medžiagą, nuoseklios mokymo programos nuo A iki C lygio kūrimas - svarbiausias mokymo kokybę užtikrinantis veiksnys. 


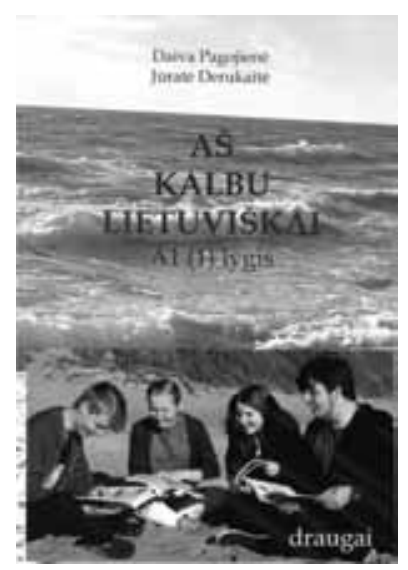

KU lietuvių kalbos kursų veikla yra pripažinta, aukštai vertinama ir nacionaliniu, ir tarptautiniu mastu. Kursų dalyvių vertinimu, KU kursai pasižymi ne tik labai gera mokymo kokybe, bet ir itin plačia bei intensyvia kultūros pažinimo programa. Tokius motyvus nurodo asmenys, dalyvaujantys KU kursuose ne pirmą kartą, atvykstantys į juos iš tolimų šalių po keletą kartų, čia mokydamiesi lietuvių kalbos nuo pradmenų iki aukščiausiojo lygio.

Norinčiųiu mokytis lietuvių kalbos motyvai įvairūs, juos galima suskirstyti į kelias kategorijas. Vietiniams kitataučiams lietuvių kalbos mokymasis kursuose yra ir svarbus adaptacijos, socializacijos veiksnys, padedantis mažinti socialinę atskirtį, susirasti bendraminčių.

Tarp lietuvių kalbos kursų dalyvių, organizatorių, dėstytojų užsimezga perspektyvūs bičiulystès, bendradarbiavimo ryšiai. Ne vienam užsieniečiui KU lietuvių kalbos kursai tapo pirmuoju sẻkmingu žingsniu, paskatinusiu studijuoti, dirbti, apsigyventi Lietuvoje. Kursų alumnai tampa lietuvių kalbos ir kultūros skleidejjais savo šalyse, kuriami bendri projektai, plečiamas mokslinis bendradarbiavimas. Taigi KU lietuvių kalbos kursai yra svarus universiteto indèlis i informacijos apie Lietuvą, jos kalbos ir kultūros sklaidą pasaulyje.

\section{Literat $\bar{u}$ ra}

Amici Lituanici. Virtualiojo klubo kitakalbiams socialinio tinklo Facebook paskyra. Prieiga internetu: <https://www.facebook.com/pg/lituanici/posts/?ref=page_internal> [žiūrèta 202007 17]. Australijos lietuvių bendruomenès laikraštis „Mūsu pastogè“, 2017-09-06, nr. 33.

Buivydienè, Žukienė 2006 - Buivydienè, V., Žukienė, R. Lietuvių kalbos kaip svetimosios mokymas(is) ir sociokultūrinis kontekstas. Santalka. Filologija. Edukologija 14 (4). Prieiga internetu: https://www.semanticscholar.org/paper/Lietuvi\%C5\%B3-kalbos-kaip-svetimosios-mokymas-\%28-is\%29-ir-Buivydien \%C4\%97-\%C5\%BDukien \%C4\%97/89135221e4c4ab9fdc3101f476ba22d752d8315c [žiūrèta 202007 17].

Karaliūnaitè, Ugnè. Filipinietis pasiryžo išmokti lietuvių - dabar jos moko kitus. Prieiga internetu: $<$ https://euroblogas.lt/2020/05/05/filipinietis-pasiryzo-ismokti-lietuviu-\%e2\%88\%92-dabarjos-moko-kitus/?fbclid=IwAR1gXeZnmfzIGKV7H5nONpuJS3EvoM9hXfXOLW46uHRZwK Pls1PPkUG78As> [žiūrèta 202007 17].

Klaipedos universiteto (KU) Socialinių ir humanitarinių mokslų fakulteto Lituanistikos ir užsienio kalbų centro archyvai.

KU lietuvių kalbos kursantų atsiliepimai. Prieiga internetu: <https://www.ku.lt/shmf/en/responses-about-summer-academy/> [Žiūrèta 202007 17].

KU lietuvių kalbos kursų informacija. Prieiga internetu: <https://www.ku.lt/shmf/struktura/centrai/kalbu-ir-socialines-edukacijos-centras/veikla/> [žiūrèta 202007 17].

Lietuvos Respublikos Seimo nutarimas „Dèl valstybinès kalbos politikos 2018-2022 metų gairių. Prieiga internetu: <https://e-seimas.lrs.lt/portal/legalAct/lt/TAD/cd0584707b6e11e89188e16a- 
6495e98c?positionInSearchResults $=0 \&$ searchModelUUID $=2$ fa062c8-0d9b-4b80-9a448938b12fe0a4> [žiūrèta 202007 17].

Rasos Kabailos blogas. Prieiga internetu: $<$ https://rakabaila.blogspot.com/2017/07/labas-lietuvagetting-back-to-my-roots.html> [žiūrèta 202007 17].

Valstybinès kalbos mokymas: lygiu aprašai ir kita informacija. Prieiga internetu: <http://www. vlkk.lt/nuorodos/kitos-nuorodos\#Valstybin> [žiūrèta 202007 17].

Vilniaus universiteto Filologijos fakulteto Lituanistikos studiju katedros svetainė. Prieiga internetu: <http://www.lsk.flf.vu.lt/lt/darbuotojai> [žiūrèta 202007 17].

Pagojienė 2017 - Pagojienė, D. Ar įmanoma išmokti lietuviškai per vienerius metus. Prieiga internetu: <http://mokslolietuva.lt/2017/04/ar-imanoma-ismokti-lietuviskai-per-vienerius-metus/> [žiūrèta 202007 17].

Nuotraukų autorius Saulius Pagojus

Iliustracijų autorė Ramunè Valeikienè

\section{Jūratė Derukaitè}

\section{THE TEACHING OF LITHUANIAN AS A FOREIGN LANGUAGE AS PART OF THE IDENTITY OF KLAIPËDA UNIVERSITY}

The informal teaching of Lithuanian as a foreign language (L2) at Klaipeda University (KU) includes semester courses and intensive summer/winter courses (the Lithuanian Language and Culture Summer/Winter Academy). It is a continuous and flexible system, and functions separately from degree studies for foreign students at KU.

This kind of informal Lithuanian studies has been carried out for 20 years, and the volume of activity has increased by approximately ten times. It is a complex structure, a growing and evolving system, and its success depends on each component, each of which could be a subject for separate research.

Nearly 3,000 people have participated in these courses over the last two decades. The Summer Academy attracts the largest number of participants (60 to 70). Most are people of other nationalities. They also include people of Lithuanian origin, and their number has been increasing.

Some participants in Lithuanian-language courses are eligible for grants from the Education Exchange Support Foundation (for the summer and winter courses), or from other sources. Other participants pay a tuition fee. In order to provide more opportunities to learn Lithuanian, the organisers should focus on more project activities, look for more opportunities to find sources to finance these studies, and offer them for free.

The participants in the courses are adults. There have only been some exceptional cases of learners under the age of 18 . Nevertheless, it is reasonable to 
offer Lithuanian lessons to children. Potential learners could be children from the families of émigrés returning to Lithuania. Moreover, pedagogical studies are carried out at $\mathrm{KU}$; therefore, there is a basis of necessary experts to teach children.

The teaching of Lithuanian as L2 is a relatively new field. Demand began to grow rapidly after Lithuania became a member of the European Union in 2004. The teachers of Lithuanian as L2 were specialists in Lithuanian philology, who had acquired the specialisation of teaching Lithuanian to non-native speakers on their own, by doing practical work, accumulating theoretical knowledge, carrying out research, and sharing experience.

There is already much material for teaching/learning Lithuanian as L2. However, some specific material is still missing. This applies specially to studies of Lithuanian at the $\mathrm{C}$ language proficiency level, and teachers at $\mathrm{KU}$ have been doing a good job at creating original material for their students. Therefore, an important part of the work is to keep collecting, creating and systematising learning resources.

The Lithuanian-language courses at KU have been recognised and appreciated at a national and international level. Along with the quality of the teaching, the cultural programme is always mentioned as the most extensive and gratifying. In this connection, it should be emphasised that nearly a third of learners have participated in Lithuanian-language courses at KU before. Some have completed all the levels of learning Lithuanian, from A1 to C2, at KU.

With regard to the motivation of people willing to learn Lithuanian, there are several categories of learners. For local non-native speakers, especially for newcomers, studies of Lithuanian, attendance on the courses, is an important factor in their adaptation and integration. According to these people, they feel as if they are in a new family in a learners' group.

Networking between participants in Lithuanian-language courses at KU and the staff (course teachers, organisers) is the basis for a growing relationship in various fields. For some learners, informal studies of Lithuanian at KU have been a successful beginning, the first step of which has prompted them to study, live and work in Lithuania. On the other hand, former students on KU's Lithuanianlanguage courses disseminate information and knowledge about the Lithuanian language and culture. Informal studies of Lithuanian at KU have been the basis for joint projects and research. Therefore, the activities in teaching Lithuanian as L2 are an important contribution by Klaipeda University both at a national and an international level. It is one of the ways of presenting Lithuania to the world, to promote its language and culture. 